\title{
Inflammatory and Anti-inflammatory Responsiveness of Surfactant Proteins in Fetal and Neonatal Rabbit Lung
}

\author{
OUTI VÄYRYNEN, VIRPI GLUMOFF, AND MIKKO HALLMAN \\ Department of Pediatrics and Biocenter Oulu, FIN-90014 University of Oulu, Finland
} \begin{abstract}
$-\mathrm{B}$, and -C. Lung explants from rabbit fetuses at 22 (immature), 27 (transitional), and 30 (mature) d of gestation (term, 30-31 d) and on $\mathrm{d} 1$ after term birth were cultured with dexamethasone (Dx), IL-1 $\alpha$, or vehicle in the presence or absence of actinomycin D. According to the present results, IL- $1 \alpha$ and Dx additively increased the expression of SP-A and SP-B on d 22. Later in gestation, SP-B and SP-C were suppressed by IL-1, whereas glucocorticoid tended to increase the expression of SP-B and
\end{abstract}

\section{ABSTRACT}

SP-C and prevented the IL-1-induced suppression of SP. IL- $1 \alpha$ and steroid interactively increased the stability of SP mRNA compared with the single agonist, possibly explaining the additive effects on the SP mRNA levels. The present results reveal beneficial additive effects of glucocorticoid and cytokine on lung surfactant. They may explain some of the acute beneficial effects of glucocorticoid therapy in chorioamnionitis before premature birth and in inflammatory lung disease after birth. (Pediatr Res 55: 55-60, 2004)
Dx, dexamethasone

\section{Abbreviations}
RDS, respiratory distress syndrome
SP, surfactant protein
LPS, lipopolysaccharide
BPD, bronchopulmonary dysplasia

The principal cause of RDS in newborns is surfactant deficiency due to immaturity of type II alveolar cells (1). Lung surfactant prevents atelectasis, contributes toward a decrease in alveolar edema and small airway closure, and is involved in pulmonary host defense. Apart from lipids, the complex contains specific SP that are bound to surfactant aggregates. SP-A is a hydrophilic C-type lectin, whereas SP-B and SP-C are hydrophobic membranous proteins. They all have highly specific roles in surfactant function $(2,3)$. Antenatal corticosteroid therapy given in the case of imminent premature birth decreases the incidence of RDS and intracranial hemorrhage (4).

Glucocorticoids have been shown to influence the expression of SP in the fetal lung (5). In human fetal lung explants,

Received February 27, 2003; accepted May 22, 2003

Correspondence: Mikko Hallman, M.D., Ph.D., Department of Pediatrics and Biocenter Oulu, University of Oulu, Kajaanintie 52, 90220 Oulu, Finland; e-mail: mikko.hallman@oulu.fi

Supported by the Academy of Finland, Biocenter Oulu (M.H.) and the Foundation for Pediatric Research in Finland (O.V.).

Preliminary results were presented as an abstract at the 1999 annual meeting of the European Society of Pediatric Research in Copenhagen (Pediatr Res 1999;45(6):31).

DOI: 10.1203/01.PDR.0000100462.41671.C6
Dx stimulated the expression of SP-A at low concentrations $\left(\leq 10^{-8} \mathrm{M}\right)$ and after short exposure $(24-48 \mathrm{~h})$ or inhibited the expression of SP-A at higher doses as well as after longer exposure (3-4 d) (6-8). The stability of SP-A mRNA decreased acutely after Dx $(8,9)$. In explants from rabbit lung, Dx $\left(10^{-7} \mathrm{M}\right)$ decreased the rate of transcription of SP-A mRNA within $24 \mathrm{~h}$, whereas the transcription rate was increased by Dx within $48 \mathrm{~h}$ (10). Both SP-B and SP-C were up-regulated by Dx in explants from mid-trimester human lung (11-13) and from fetal rabbit during the third trimester (1416), whereas SP-C was unaffected in 30-d-old fetal rabbit lung (17).

Chorioamnionitis is the main setting associated with very premature birth. In this condition, the concentrations of IL-1 $\alpha$ and IL-1 $\beta$ (18) and other cytokines (19) are increased in the amniotic fluid and in the airways shortly after birth (20). In very premature infants born due to intrauterine infection, the incidence of RDS is lower than could be expected on the basis of their very early birth (21). Premature infants who were more mature than in the series of Watterberg et al. (21) showed an increased incidence of RDS in intrauterine infection (22). 
When given intra-amniotically to immature rabbit or sheep, IL- $1 \alpha$ increases SP-A and SP-B mRNA and decreases the severity of RDS after premature birth $(23,24)$. As studied in lung explants, IL- $1 \alpha$ has a biphasic influence on the expression of SP, increasing SP-A and SP-B mRNA in very premature lung and decreasing the expression SP-B and SP-C in transitional and mature lung (25).

Antenatal glucocorticoid therapy may decrease the incidence of RDS, brain damage, and neonatal death after preterm birth due to intrauterine inflammatory syndrome $(4,26)$. In immature lung, both proinflammatory cytokines and the antiinflammatory glucocorticoid influence lung maturity and the differentiation of the surfactant complex. The aim of the present study was to investigate the interactions of a cytokine (IL-1 $\alpha$ ) and a glucocorticoid (Dx) in the expression of SP in explants recovered from rabbit lung during the last trimester and the perinatal period.

\section{MATERIALS AND METHODS}

Animal protocol. The Animal Research Committee in the University of Oulu approved the protocol. The mating date of the New Zealand White rabbits used in the experiment was defined as d 0 of gestation. On d 22, 27, or 30 ( $\pm 1 \mathrm{~h})$ of pregnancy (term, 30-31 d), the does were anesthetized with medetomidine $(0.3 \mathrm{mg} / \mathrm{kg}$ i.m.) and ketamine $(20 \mathrm{mg} / \mathrm{kg}$ i.m.). Hysterotomy was performed, and shortly after that, i.v. pentobarbital was given to the doe. The pups were killed by decapitation, and the abdominal aorta was severed. The lungs were recovered under sterile conditions. In addition, 1-d-old newborn rabbits were killed and the lungs were recovered.

Recombinant human IL- $1 \alpha$ (rhIL-1 $\alpha$ ) (endotoxin content $<0.01 \%$ of dry wt) was a generous gift of Dr. R. Chizzonite (Hoffmann LaRoche, Nutley, NJ, U.S.A.). RhIL- $1 \alpha$ is biologically active in rabbit (27). Dx and actinomycin D were purchased from Sigma-Aldrich (Helsinki, Finland).

Organ culture. The organ culture conditions have been described previously (25). Briefly, in one experiment the lungs recovered from all fetuses from the litter were mixed and cut into cubes (approximately $2 \mathrm{~mm}^{3}$ each). Five of such pieces were placed on a filter paper that was on a metallic grid in a culture dish. The tissue was maintained in culture for $20 \mathrm{~h}$. Thereafter, IL- $1 \alpha$, Dx, or vehicle was added and incubation was continued for the next $20 \mathrm{~h}$, unless otherwise indicated. After the culture, lung tissue explants from one culture dish were harvested in a microcentrifuge tube, frozen in liquid nitrogen, and stored at $-70^{\circ} \mathrm{C}$, until processed for mRNA analysis.

Analysis of $\boldsymbol{m R N A}$. RNA was isolated and blotted as described previously (25). The membranes were hybridized using probes of $1.9 \mathrm{~kb}$ rabbit SP-A cDNA, $0.6 \mathrm{~kb}$ rabbit SP-B cDNA, or $0.5 \mathrm{~kb}$ rabbit SP-C cDNA (23). The purified inserts were labeled with ${ }^{32} \mathrm{P}$ using the oligolabeling kit from Amersham Pharmacia Biotech AB (Uppsala, Sweden). To compensate for gel-loading artifacts, the membranes were probed with ${ }^{32} \mathrm{P}$ radiolabeled 28S RNA-specific cDNA clone. The bands were quantified using PhosphorImager.
Expression of results and statistics. The mRNA levels of SP-A, SP-B, and SP-C are presented as means \pm SEM for convenience. mRNA in the presence of IL-1, Dx, and the combination of IL-1 and Dx is expressed relative to mRNA vehicle-treated controls, respectively. The number of independent mRNA analyses is shown as $n$. Statistical significance was analyzed using independent samples $t$ test. When indicated, ANOVA followed by post hoc analysis with the Scheffé test was performed. A $p$ value $<0.05$ was considered as significant.

\section{RESULTS}

Influence of the agonist on the expression of SP as a function of age. The explants from d 22 and d 30 fetal lung were exposed to Dx $\left(3 \times 10^{-9} \mathrm{M}-10^{-6} \mathrm{M}\right), \mathrm{IL}-1 \alpha(57 \mathrm{ng} / \mathrm{mL}$ or $570 \mathrm{ng} / \mathrm{mL})$, or a combination of Dx $\left(10^{-7} \mathrm{M}\right)$ and IL- $1 \alpha$ for $20 \mathrm{~h}$. In immature lung explants from $22 \mathrm{~d}$ gestation, SP-A expression was not acutely affected by Dx at any concentration, whereas both concentrations of IL- $1 \alpha$ up-regulated the expression of SP-A mRNA. Dx at $10^{-7} \mathrm{M}$ increased the effect of IL-1 on the expression of SP-A mRNA additively. At the high concentration of IL- $1 \alpha(570 \mathrm{ng} / \mathrm{mL})$, the additive effect Dx was statistically significant $(p=0.04)$ (Fig. $1 A)$. In contrast to SP-A, $10^{-7} \mathrm{M}$ Dx increased SP-B expression $3.5 \pm 0.5$-fold in immature lung, and the increase in SP-B expression was evident at Dx concentrations ranging from $3 \times 10^{-9} \mathrm{M}$ to $10^{-6}$ $\mathrm{M}$ (data not shown). The combined effect of Dx and IL- $1 \alpha$ on SP-B expression tended to be additive (Fig. $1 A$ ). IL-1 at 57 $\mathrm{ng} / \mathrm{mL}$ or both Dx and IL-1 (57 ng/mL or $570 \mathrm{ng} / \mathrm{mL})$ had no significant effect on the expression of SP-C in explants from 22-d-old fetal lung; IL-1 $\alpha$ at $570 \mathrm{ng} / \mathrm{mL}$ decreased SP-C mRNA in this setting. Dx at $10^{-7} \mathrm{M}(n=4)$ had a nonsignificant increasing effect on the expression of SP-C in the test documenting the interaction of Dx and IL-1 (Fig. 1A). However, concentration studies revealed a $1.6 \pm 0.24$-fold $(p=$ $0.027)$ up-regulation of SP-C mRNA by Dx at $10^{-7} \mathrm{M}(n=$ 11).

In $30 \mathrm{~d}$ term fetal lung, Dx at $10^{-7} \mathrm{M}$ did not influence the expression of SP-A mRNA, whereas IL- $1 \alpha$ at $570 \mathrm{ng} / \mathrm{mL}$ down-regulated SP-A. This decrease was abolished by Dx (Fig. $1 B$ ). IL-1 suppressed the expression of hydrophobic SP, SP-B, and SP-C by approximately $50 \%$ (Fig. $1 B$ ), whereas Dx at $3 \times$ $10^{-9} \mathrm{M}, 10^{-7} \mathrm{M}$, and $10^{-6} \mathrm{M}$ increased the SP-B expression $1.8 \pm 0.24(n=4, p<0.05), 1.6 \pm 0.13(n=6, p<0.05)$, and $1.4 \pm 0.17(n=6, p<0.05)$-fold, respectively. In contrast, SP-C mRNA was unaffected by any concentration of Dx. Similarly to SP-B, Dx reduced or abolished the suppression of SP-C by IL-1 $\alpha$ (Fig. $1 B)$.

The effects of Dx $\left(10^{-7} \mathrm{M}\right), \mathrm{IL}-1 \alpha(57 \mathrm{ng} / \mathrm{mL})$, and the combination of Dx and IL-1 on the expression of SP-A, -B, and -C were studied in transitional (27-d-old fetal), and newborn (1-d-old) lung (Table 1). The influences of Dx, IL-1, and the combinations of Dx and IL-1 on the expression of SP were similar in transitional and mature fetal as well as in newborn lung and distinctly different in immature lung. As a conclusion, Dx increased (d 22, 27, 30 in fetus) or tended to increase (d 1 in newborn) the expression of SP-B mRNA at all ages. In 

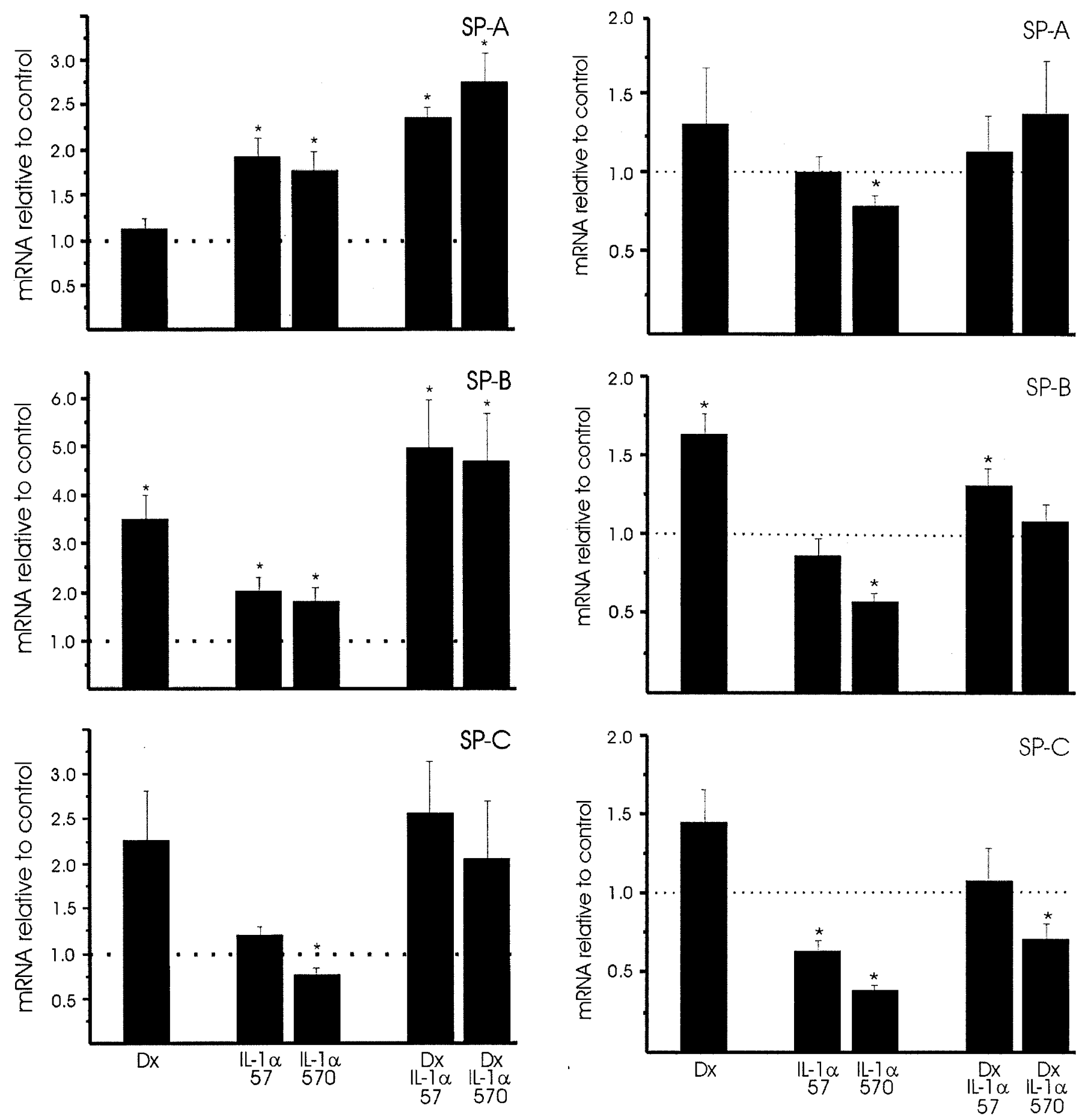

Figure 1. Expression of SP-A, SP-B, and SP-C mRNA in explants from fetal rabbit lung on d $22(A)$ and d $30(B)$ of gestation. Effect of Dx $\left(10^{-7} \mathrm{M}\right)(n=$ 4), IL-1 $\alpha(57 \mathrm{ng} / \mathrm{mL}$ and $570 \mathrm{ng} / \mathrm{mL})(n=6)$, and a combination of Dx $\left(10^{-7} \mathrm{M}\right)$ and IL- $1 \alpha(57 \mathrm{ng} / \mathrm{mL}$ and $570 \mathrm{ng} / \mathrm{mL})(n=4)$ on SP-A, $-\mathrm{B}$, and $-\mathrm{C}$ mRNA expression in explants from fetal lung. The explants were incubated in the presence of agonist or vehicle for $20 \mathrm{~h}$. The bars show the SP expression levels relative to expression in the presence of vehicle (shown as a dotted line). The data are means \pm SEM. ${ }^{*} p<0.05$ compared with vehicle.

immature lung Dx had an additive effect on the IL-1-induced up-regulation of SP-A and SP-B mRNA, whereas in transitional and mature lung Dx abolished the IL- $1 \alpha$ induced suppression on SP-B and SP-C expression.

Stability of $\boldsymbol{m} \boldsymbol{R} \boldsymbol{N} \boldsymbol{A}$. We studied the stability of SP-A, -B, and $-\mathrm{C}$ mRNA in the lung explants from 22- and 27-d-old rabbit fetuses. The content of SP mRNA was studied after the addi- tion of actinomycin $\mathrm{D}$, an inhibitor of mRNA synthesis. After preincubation for $20 \mathrm{~h}$ in serum-free Waymouth's media, IL-1 (570 ng/mL), Dx $\left(10^{-7} \mathrm{M}\right)$, or a combination of IL-1 and Dx was added, or the media was changed for the control explants. Four hours later, actinomycin D ( 5 or $15 \mu \mathrm{g} / \mathrm{mL}$ ) was added. The mRNA value at that zero time point, i.e. $4 \mathrm{~h}$ after the addition of agonists, was considered to be $100 \%$. The levels of 
Table 1. Effect of $D x, I L-1 \alpha$, and combination of $D x$ and $I L-1 \alpha$ on the surfactant protein- $A$, $-B$, and $-C m R N A$

\begin{tabular}{|c|c|c|c|c|c|c|c|c|c|}
\hline \multirow[b]{2}{*}{ Age } & \multicolumn{3}{|c|}{ SP-A } & \multicolumn{3}{|c|}{ SP-B } & \multicolumn{3}{|c|}{ SP-C } \\
\hline & $\begin{array}{c}\text { Dx } \\
\left(10^{-7} \mathrm{M}\right)\end{array}$ & $\begin{array}{c}\mathrm{IL}-1 \alpha \\
(57 \mathrm{ng} / \mathrm{mL})\end{array}$ & $\mathrm{Dx}+\mathrm{IL}-1 \alpha$ & $\begin{array}{c}\text { Dx } \\
\left(10^{-7} \mathrm{M}\right)\end{array}$ & $\begin{array}{c}\mathrm{IL}-1 \alpha \\
(57 \mathrm{ng} / \mathrm{mL})\end{array}$ & $\mathrm{Dx}+\mathrm{IL}-1 \alpha$ & $\begin{array}{c}\text { Dx } \\
\left(10^{-7} \mathrm{M}\right)\end{array}$ & $\begin{array}{c}\mathrm{IL}-1 \alpha \\
(57 \mathrm{ng} / \mathrm{mL})\end{array}$ & $\mathrm{Dx}+\mathrm{IL}-1 \alpha$ \\
\hline Fetus $27 \mathrm{~d}$ & $1.1 \pm 0.1$ & $1.1 \pm 0.1$ & $1.1 \pm 0.1$ & $2.4 \pm 0.2^{*}$ & $0.9 \pm 0.1$ & $1.9 \pm 0.3$ & $1.2 \pm 0.1$ & $0.5 \pm 0.1^{*}$ & $1.0 \pm 0.1$ \\
\hline Newborn $1 \mathrm{~d}$ & $1.1 \pm 0.1$ & $1.1 \pm 0.1$ & $1.3 \pm 0.1$ & $1.3 \pm 0.2$ & $0.7 \pm 0.0^{*}$ & $1.4 \pm 0.2$ & $1.2 \pm 0.1$ & $0.6 \pm 0.0^{*}$ & $1.0 \pm 0.1$ \\
\hline
\end{tabular}

SP-A, SP-B, and SP-C mRNA levels are presented as mean \pm SEM on the basis of the vehicle-treated controls $(* p<0.05)$.

mRNA were measured at 4, 6, 8, and $16 \mathrm{~h}$ (Fig. 2). In explants from immature lung, IL-1 and Dx tended to increase the degradation of SP-A mRNA compared with vehicle-treated tissue. However, when added together, these agents tended to stabilize SP-A mRNA. Dx decreased the stability of SP-B mRNA, whereas in the presence of IL- $1 \alpha$ or IL- $1 \alpha$ and Dx, mRNA stability was unaffected. In contrast, IL- $1 \alpha$ decreased the stability of SP-C mRNA, whereas Dx or IL- $1 \alpha$ and Dx had no detectable effect. In 27-d fetal explants, on the other hand, IL-1 increased the degradation of SP-A, SP-B, and SP-C mRNA. Dx together with IL-1 tended to stabilize SP-B and SP-C mRNA.

\section{DISCUSSION}

We report evidence of additive up-regulation of SP-A and SP-B mRNA expression by IL- $1 \alpha$ and Dx in immature fetal lung in vitro. In contrast, in transitional and mature lung, Dx increased the expression of SP-B and SP-C and abolished the inhibitory effects of IL-1 on these proteins.

The suppression of SP-B and SP-C expression by IL-1 in transitional lung was found to be associated with decreased mRNA stability. Although Dx up-regulated the expression of SP-B, the stability of SP-B mRNA was not increased, suggesting that the increase in mRNA was controlled by the rate of transcription (28). In immature lung, Dx tended to acutely decrease the stability of SP-B mRNA in contrast to the previously reported increase in SP-B half-life in 21-d fetal rabbit lung after prolonged exposure to steroid (15). Margana and Boggaram (15) exposed the explants to Dx for $5 \mathrm{~d}$ versus $20 \mathrm{~h}$ in the present study. Spontaneous differentiation of lung takes place during culture in vitro (29). This could alter the steroid or cytokine responsiveness. Thus, in explants from immature lung after a prolonged culture period or in explants from transitional lung after a brief period of culture (d 27 in this study), steroid or cytokine responsiveness resembles the responses seen at a more advanced stage of differentiation. The stability of SP-B mRNA in transitional and mature rabbit lung has not been studied previously. No increase in the SP-B transcription rate was evident when lung explants from 26- or 30-d fetal rabbits were exposed to Dx for $48 \mathrm{~h}$ (16). In human mid-trimester lung, the up-regulation of SP-B mRNA was found to be due to an increased rate of gene transcription as well as increased mRNA stability (30). Any evaluation of the differences between the glucocorticoid and cytokine effects in the different experimental designs is difficult. According to the present results, the Dx-induced acute up-regulation of SP-B expression in very premature as well as in transitional/mature lung is likely to be due to an increase in the transcription rate.
IL-1 $(23,24)$ or LPS $(31,32)$ administered intraamniotically to fetal rabbit and sheep accelerates lung maturation by improving respiratory function after premature birth and increasing the expression of SP-A and SP-B. In lamb fetuses, the expression of SP-C was increased as well (33). Maternal betamethasone also increased SP-A, -B, and -C mRNA (34) and improved lung function in preterm lamb (35), although less than IL-1 (24) or LPS (32). When maternal betamethasone treatment was combined with intra-amniotic endotoxin, lung function improved synergistically, even though the effect on the surfactant phospholipid content was not additive (36). Here, we show that, in immature lung, glucocorticoid and IL-1 increased additively or synergistically the expression of SP-A and SP-B and tended to stabilize the SP-A and SP-B mRNA consistently with the additive effect. The present study further provided evidence indicating that, in explants from more mature lung, Dx decreased the IL-1induced degradation of SP-B and SP-C mRNA. This seems to explain the finding that Dx restored the mRNA levels of SP-B and SP-C, which were decreased by IL- $1 \alpha$. Thus, IL-1 and Dx tended to cooperatively stabilize SP-B mRNA regardless of age.

The decreasing effect of LPS (37) and IL-1 (33) on the severity of RDS has been associated with a dose-dependent increase in the pulmonary inflammatory cell response. In the present in vitro setting, however, the effect of IL-1 on the expression of SP-A and SP-B takes place acutely in the absence of inflammatory cell accumulation. This implies that the cytokine-induced recruitment of inflammatory cells and the cytokine induction of SP are independent processes, although they proceed in parallel in vivo.

The present results support the evidence showing that antenatal glucocorticoid prevents RDS in intrauterine inflammation, and that the treatment may be beneficial even close to term $(4,26)$. In infants born after $31 \mathrm{wk}$ of gestation, the risk of RDS was significantly higher in preterm premature rupture of fetal membranes than in gestational controls without antenatal steroid prophylaxis (22). This finding is consistent with experimental evidence $(25,38)$. After birth, a strong inflammatory reaction is evident in the airways and alveolar spaces in BPD (39) and in acute RDS (40). In acute RDS, the levels of SP-B decrease in bronchoalveolar lavage fluid (41). The steroid-induced acute decrease of respiratory failure in postnatal infants developing BPD is due to multiple, insufficiently characterized effects (42). Here, we propose that the steroidinduced stability of SP-B and SP-C mRNA increases the translation products that are critical determinants of surfactant 

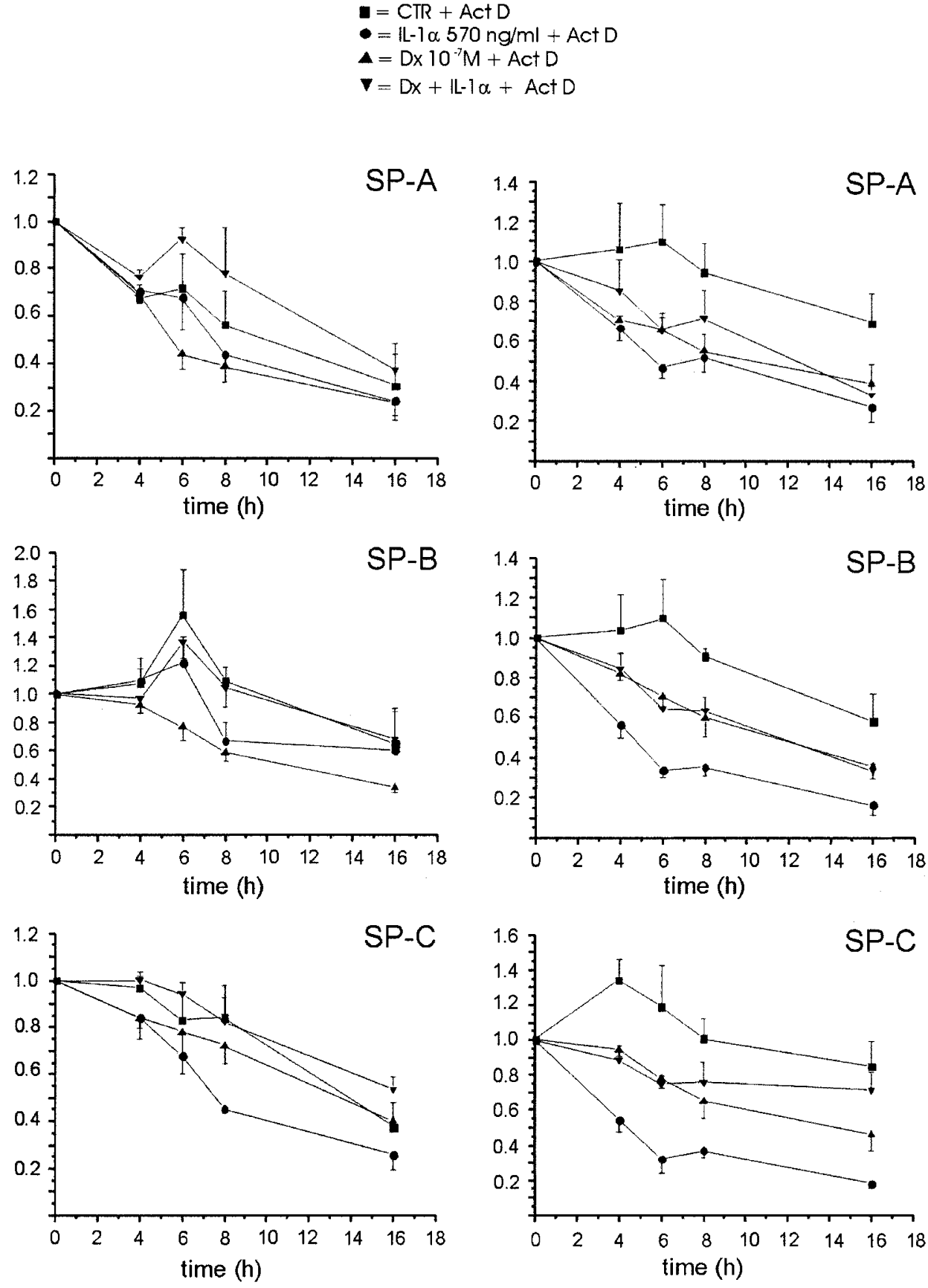

22-day old fetus

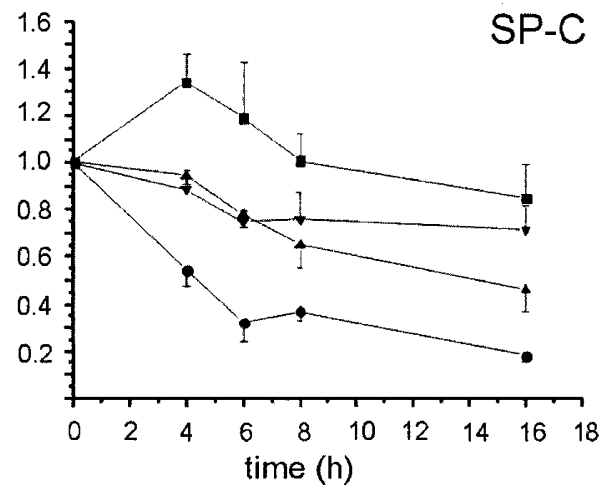

27-day old fetus

Figure 2. Stability of SP-A, SP-B, and SP-C mRNA in lung explants from 22-d and 27-d-old fetal rabbits. The lung explants were preincubated for $20 \mathrm{~h}$ in serum-free Waymouth's media. Thereafter, IL-1 $(570 \mathrm{ng} / \mathrm{mL})$, Dx $\left(10^{-7} \mathrm{M}\right)$, or a combination of IL-1 and Dx was added to the test explants, and media were changed for the control explants. Four hours later, actinomycin D $(5$ or $15 \mu \mathrm{g} / \mathrm{mL})$ was added. The mRNA values at that zero time point, i.e. $4 \mathrm{~h}$ after the addition of agonists, were considered to be 1 . The levels of mRNA were measured at $4,6,8$, and $16 \mathrm{~h}$ and expressed as means \pm SEM $(n=4)$. Both actinomycin D concentrations gave very similar results, and the mRNA values of both concentrations were combined.

function and necessary for alveolar stability. This could contribute toward the decrease in respiratory failure following near-term antenatal (4) or postnatal steroid treatments given in imminent or established BPD (43).

The present in vitro model allows study of the mechanism of action of different pharmacologic agents on the surfactant system during the perinatal period. This approach has some limitations. The model is not physiologic, i.e. the differentia- tion takes place spontaneously without added agonists, and it is difficult to relate the dose responsiveness rates of the steroid or cytokine in vitro and in vivo. However, the cytokine-induced expression of SP mRNA has also been shown at the level of SP $(25,38)$. In addition, the documented cytokine and glucocorticoid effects in vitro reveal similarities compared with animal experiments demonstrating a decrease in the severity of RDS. More prospective studies are needed to determine the most 
favorable and safe corticosteroid dosage in imminent premature birth and in severe respiratory failure after birth.

Acknowledgments. The authors thank Dr. Tiina Kangas for her help in the project as well as Maarit Hännikäinen, Elsi Jokelainen, and Mirkka Parviainen for their excellent technical assistance.

\section{REFERENCES}

1. Hallman M, Glumoff V, Ramet M 2001 Surfactant in respiratory distress syndrome and lung injury. Comp Biochem Physiol A Mol Integr Physiol 129:287-294

2. Hawgood S, Clements JA 1990 Pulmonary surfactant and its apoproteins. J Clin Invest 86:1-6

3. Creuwels LA, van Golde LM, Haagsman HP 1997 The pulmonary surfactant system: biochemical and clinical aspects. Lung 175:1-39

4. Crowley PA 1995 Antenatal corticosteroid therapy: a meta-analysis of the randomized trials, 1972 to 1994. Am J Obstet Gynecol 173:322-335

5. Odom MJ, Ballard PL 1997 Developmental and hormonal regulation of the surfactant system. In: McDonald J (ed) Lung Growth and Development. Dekker, New York, pp 495-575

6. Odom MJ, Snyder JM, Boggaram V, Mendelson CR 1988 Glucocorticoid regulation of the major surfactant associated protein (SP-A) and its messenger ribonucleic acid and of morphological development of human fetal lung in vitro. Endocrinology 123:1712-1720

7. Liley HG, White RT, Benson BJ, Ballard PL 1988 Glucocorticoids both stimulate and inhibit production of pulmonary surfactant protein A in fetal human lung. Proc Natl Acad Sci U S A 85:9096-9100

8. Iannuzzi DM, Ertsey R, Ballard PL 1993 Biphasic glucocorticoid regulation of pulmonary SP-A: characterization of inhibitory process. Am J Physiol 264:L236L244

9. Boggaram V, Smith ME, Mendelson CR 1989 Regulation of expression of the gene encoding the major surfactant protein (SP-A) in human fetal lung in vitro. Disparate effects of glucocorticoids on transcription and on mRNA stability. J Biol Chem 264:11421-11427

10. Boggaram V, Mendelson CR 1988 Transcriptional regulation of the gene encoding the major surfactant protein (SP-A) in rabbit fetal lung. J Biol Chem 263:1906019065

11. Whitsett JA, Weaver TE, Clark JC, Sawtell N, Glasser SW, Korfhagen TR, Hull WM 1987 Glucocorticoid enhances surfactant proteolipid Phe and pVal synthesis and RNA in fetal lung. J Biol Chem 262:15618-15623

12. Liley HG, White RT, Warr RG, Benson BJ, Hawgood S, Ballard PL 1989 Regulation of messenger RNAs for the hydrophobic surfactant proteins in human lung. J Clin Invest 83:1191-1197

13. Beers MF, Shuman H, Liley HG, Floros J, Gonzales LW, Yue N, Ballard PL 1995 Surfactant protein B in human fetal lung: developmental and glucocorticoid regulation. Pediatr Res 38:668-675

14. Boggaram V, Margana RK 1994 Developmental and hormonal regulation of surfactant protein C (SP-C) gene expression in fetal lung. Role of transcription and mRNA stability. J Biol Chem 269:27767-27772

15. Margana RK, Boggaram V 1995 Transcription and mRNA stability regulate developmental and hormonal expression of rabbit surfactant protein B gene. Am J Physiol 268:L481-L490

16. Xu J, Possmayer F 1993 Exposure of rabbit fetal lung to glucocorticoids in vitro does not enhance transcription of the gene encoding pulmonary surfactant-associated protein-B (SP-B). Biochim Biophys Acta 1169:146-155

17. Xu J, Yao LJ, Possmayer F 1995 Regulation of mRNA levels for pulmonary surfactant-associated proteins in developing rabbit lung. Biochim Biophys Acta 1254:302-310

18. Romero R, Mazor M, Brandt F, Sepulveda W, Avila C, Cotton DB, Dinarello CA 1992 Interleukin-1 alpha and interleukin-1 beta in preterm and term human parturition. Am J Reprod Immunol 27:117-123
19. Romero R, Mazor M, Sepulveda W, Avila C, Copeland D, Williams J 1992 Tumor necrosis factor in preterm and term labor. Am J Obstet Gynecol 166:1576-1587

20. Kotecha S, Wilson L, Wangoo A, Silverman M, Shaw RJ 1996 Increase in interleukin (IL)- 1 beta and IL- 6 in bronchoalveolar lavage fluid obtained from infants with chronic lung disease of prematurity. Pediatr Res 40:250-256

21. Watterberg KL, Demers LM, Scott SM, Murphy S 1996 Chorioamnionitis and early lung inflammation in infants in whom bronchopulmonary dysplasia develops. Pediatrics 97:210-215

22. Hallak M, Bottoms SF 1993 Accelerated pulmonary maturation from preterm premature rupture of membranes: a myth. Am J Obstet Gynecol 169:1045-1049

23. Bry K, Lappalainen U, Hallman M 1997 Intraamniotic interleukin-1 accelerates surfactant protein synthesis in fetal rabbits and improves lung stability after premature birth. J Clin Invest 99:2992-2999

24. Emerson GA, Bry K, Hallman M, Jobe AH, Wada N, Ervin MG, Ikegami M 1997 Intra-amniotic interleukin-1 alpha treatment alters postnatal adaptation in premature lambs. Biol Neonate 72:370-379

25. Glumoff V, Vayrynen O, Kangas T, Hallman M 2000 Degree of lung maturity determines the direction of the interleukin-1-induced effect on the expression of surfactant proteins. Am J Respir Cell Mol Biol 22:280-288

26. Elimian A, Verma U, Beneck D, Cipriano R, Visintainer P, Tejani N 2000 Histologic chorioamnionitis, antenatal steroids, and perinatal outcomes. Obstet Gynecol 96:333336

27. Kulkarni PS, Mancino M 1993 Studies on intraocular inflammation produced by intravitreal human interleukins in rabbits. Exp Eye Res 56:275-279

28. Ballard PL, Ertsey R, Gonzales LW, Gonzales J 1996 Transcriptional regulation of human pulmonary surfactant proteins SP-B and SP-C by glucocorticoids. Am J Respir Cell Mol Biol 14:599-607

29. Snyder JM, Johnston JM, Mendelson CR 1981 Differentiation of type II cells of human fetal lung in vitro. Cell Tissue Res 220:17-25

30. Venkatesh VC, Iannuzzi DM, Ertsey R, Ballard PL 1993 Differential glucocorticoid regulation of the pulmonary hydrophobic surfactant proteins SP-B and SP-C. Am J Respir Cell Mol Biol 8:222-228

31. Bry K, Lappalainen U 2001 Intra-amniotic endotoxin accelerates lung maturation in fetal rabbits. Acta Paediatr 90:74-80

32. Jobe AH, Newnham JP, Willet KE, Sly P, Ervin MG, Bachurski C, Possmayer F, Hallman M, Ikegami M 2000 Effects of antenatal endotoxin and glucocorticoids on the lungs of preterm lambs. Am J Obstet Gynecol 182:401-408

33. Willet KE, Kramer BW, Kallapur SG, Ikegami M, Newnham JP, Moss TJ, Sly PD, Jobe AH 2002 Intra-amniotic injection of IL-1 induces inflammation and maturation in fetal sheep lung. Am J Physiol 282:L411-L420

34. Tan RC, Ikegami M, Jobe AH, Yao LY, Possmayer F, Ballard PL 1999 Developmental and glucocorticoid regulation of surfactant protein mRNAs in preterm lambs. Am J Physiol 277:L1142-L1148

35. Rebello CM, Ikegami M, Polk DH, Jobe AH 1996 Postnatal lung responses and surfactant function after fetal or maternal corticosteroid treatment. J Appl Physiol $80: 1674-1680$

36. Newnham JP, Moss TJ, Padbury JF, Willet KE, Ikegami M, Ervin MG, Sly P, Jobe A 2001 The interactive effects of endotoxin with prenatal glucocorticoids on shortterm lung function in sheep. Am J Obstet Gynecol 185:190-197

37. Kramer BW, Moss TJ, Willet KE, Newnham JP, Sly PD, Kallapur SG, Ikegami M, Jobe AH 2001 Dose and time response after intraamniotic endotoxin in preterm lambs. Am J Respir Crit Care Med 164:982-988

38. Vayrynen O, Glumoff V, Hallman M 2002 Regulation of surfactant proteins by LPS and proinflammatory cytokines in fetal and newborn lung. Am J Physiol Lung Cell Mol Physiol 282:L803-L810

39. Speer CP 1999 Inflammatory mechanisms in neonatal chronic lung disease. Eur J Pediatr 158(suppl 1):S18-S22

40. Gunther A, Ruppert C, Schmidt R, Markart P, Grimminger F, Walmrath D, Seeger W 2001 Surfactant alteration and replacement in acute respiratory distress syndrome. Respir Res 2:353-364

41. Gregory TJ 1991 Surfactant chemical composition and biophysical activity in acute respiratory distress syndrome. J Clin Invest 88:1976-1981

42. Bolt RJ, van Weissenbruch MM, Lafeber HN, Delemarre-van de Waal HA 2001 Glucocorticoids and lung development in the fetus and preterm infant. Pediatr Pulmonol 32:76-91

43. Cole CH 2000 Postnatal glucocorticosteroid therapy for treatment and prevention of neonatal chronic lung disease. Expert Opin Investig Drugs 9:53-67 